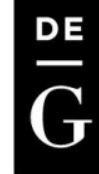

DE GRUYTER

OPEN

DOI 10.2478/pesd-2014-0033

PESD, VOL. 8, no. 2, 2014

\title{
ZINC REGIME IN THE SEWAGE SLUDGE-SOIL-PLANT SYSTEM OF A CITY WASTE WATER TREATMENT POND
}

\section{Radu Lacatusu ${ }^{1}$, Anca-Rovena Lacatusu ${ }^{1}$, Mihaela Lungu ${ }^{1}$, Mihaela Monica Stanciu Burileanu ${ }^{1}$, Andrei Vrînceanu ${ }^{1}$}

Key words: sewage sludge, zinc, pollution, phytoremediation, fertilization.

\begin{abstract}
The sewage sludge from wastewater treatment plant of Iasi, a city with 300,000 inhabitants, for domestic and industrial origin, was stored in a mud pond arranged on an area of $18,920 \mathrm{~m}^{2}$. Chemical analyzes of the sludge showed that, of all the chemical elements determined, only $\mathrm{Zn}$ is found at pollutant level (5739 $\mathrm{mg} \cdot \mathrm{kg}^{-1}$ ), i.e. almost 30 times more than the maximum allowable limit for $\mathrm{Zn}$ in soil and 45 times more than the $\mathrm{Zn}$ content of the soil on which the mud pond has been set. Over time, the content of $\mathrm{Zn}$ in the mud pond, but also from soil to which it has been placed, has become upper the normal content of the surrounding soil up to a depth of $260 \mathrm{~cm}$. On the other hand, the vegetation installed on sewage sludge in the process of mineralization, composed predominantly of Phragmites, Rumex, Chenopodium, and Aster species had accumulated in roots, stems and leaves $\mathrm{Zn}$ quantities equivalent to $1463 \mathrm{mg} \mathrm{Kg}^{-1}, 3988 \mathrm{mg} \mathrm{Kg}^{-1}, 1463 \mathrm{mg} \mathrm{Kg}^{-1}$, respectively, $1120 \mathrm{mg} \cdot \mathrm{Kg}^{-1}$. The plants in question represents the natural means of phytoremediation, and sewage sludge as such may constitute a fertilizer material for soils in the area, on which $\mathrm{Zn}$ deficiency in maize has been recorded. In addition, the ash resulted from the incineration of plants loaded with zinc may constitute, in its turn, a good material for fertilizing of the soils that are deficient in zinc.
\end{abstract}

\section{Introduction}

Sewage sludge from municipal wastewater treatment plant belonging to Iasi, a city with approx. 300,000.00 inhabitants was deposited in a mud pond located about $2 \mathrm{~km}$ from the station, on the land belonging to Tomeşti village, located in the floodplain of the river Bahlui, with an area of about 19 ha. The deposit was built in 1994 by removing the topsoil from an area of 9.1 ha and the construction of dikes surrounding and separating. The deposit was divided into 11 compartments

\footnotetext{
${ }^{1}$ Institutul National de Cercetare Dezvoltare pentru Pedologie, Agrochimie si Protecția Mediului-ICPA, Bucuresti; radu.lacatusu@icpa.ro
} 
with different surfaces. Between compartments there are gaps for water and mud movement. The total volume of the deposit is $225,000.00 \mathrm{~m} 3$.

Due to the combined processes of flotation, drying and drainage the sludge has thickened. But the intake of rainfall water contributed largely to maintain a liquid blanket above the mud. As a result of oscillations between the amount of rainfall and evapotranspiration and infiltration intensity, depth of the mud, including water mirror oscillate between 1.5 and $2 \mathrm{~m}$. With time, starting from the basins edges, where the mud in a semi-dry state is prevailing for a longer period of time, has been installed predominantly reed vegetation, vegetation that has developed gradually from the edges toward the center, as the lower prevalence of the liquid phase and the beginning of the soil formation process.

In order to find solutions for greening this mud pond, the sludge was chemically analyzed, leading to the conclusion that of all the chemical elements analyzed only zinc content shows very high levels, with an appreciable potential pollutant effect (Lăcătuşu et al., 2005, 2012) . Therefore, in this paper we present this heavy metal regime in sludge, in plants grown on it and in the soil on which the mud pond has been set.

\section{Material and methods}

The sludge samples were collected from a drilling rig, carried out of 20 to 20 $\mathrm{cm}$ depth of up to $200 \mathrm{~cm}$. From the other five points, also located in the marginal zone of the mud pond, samples were collected only on the depths of $0-20 \mathrm{~cm}$ and $20-40 \mathrm{~cm}$. Around the locations where the samples were the half-mineralized sludge were been sampled, plant samples were collected both by species and anatomical parts (root and aerial part). In parallel, soil samples from a profile carried out near the waste area were been collected.

Sludge and soil samples were been analyzed in the laboratory, following determinations being performed: humidity, granulometry after STAS7184 / 10 (1979), the organic C content by Walkley-Black method modified by Gogoașă, total soluble salts contents by conductometry determination. Mobile forms of nitrogen $\left(\mathrm{NO}_{3}{ }^{-}\right)$, phosphorus and potassium (soluble in the ammonium-acetatelactate solution at $\mathrm{pH}$ 3.7) were determined by ion selective potentiometer (nitrates), spectrophotometry (phosphorus), and flam photometry (potassium), and the total $\mathrm{Zn}$ content in soil samples were been measured by flame atomic absorption spectrometry. The total $\mathrm{Zn}$ content in plants was carried out in hydrochloric solution resulted by solubilization of plant ash (obtained after several hours calcination at $450^{\circ} \mathrm{C}$ ), using also the atomic absorption spectrometry.

Analytical methods are in accordance with national (STAS) and international (ISO) standards. 
Analytical data were statistically computed, statistical parameters $\left(\mathrm{X}_{\min }\right.$, $\mathrm{X}_{\max }, \bar{X} \sigma, \mathrm{CV}, \mathrm{X}_{\mathrm{g}}, \mathrm{Me}, \mathrm{Mo}$ ) and the correlations between $\mathrm{Zn}$ contents and sludge and aerial part of plants samples were been investigated.

\section{Results and discussions}

\subsection{Chemical characterization of the sludge and the soil surrounding mud} pond area

Sewage sludge is a pasty mass of black or brown color, depending on the intensity of oxidation-reduction process. Sewage sludge has a weak alkaline reaction, a moderate content of $\mathrm{CaCO}_{3}$, but a higher, even very high organic carbon and total nitrogen contents. The higher value of $\mathrm{C} / \mathrm{N}$ ratio expresses the excess of organic $\mathrm{C}$, which thus increases the ratio of five units from the normal value of $\mathrm{C} / \mathrm{N}$ ratio of soil existing on the land surrounding the mud pond. There are also characteristic the very large values of the contents in mobile forms of nitrogen, phosphorus and potassium. As compared to the contents of the same chemical parameters in soil, in sewage sludge can be found 22 times more nitric nitrogen, 13 times more mobile phosphorus and 1.2 times more mobile potassium.

Soil, a strongly salinized aluviosol in the depth, also has a weak alkaline reaction; medium carbonates content, but a much lower content of organic $\mathrm{C}$, and almost eight times less than sewage sludge. The humus content $(2,8 \%)$ of the soil falls into the middle class. Also, the average content of total $\mathrm{N}$ falls in the middle class content. Sewage sludge moisture, even at the edge of the mud pond, was nearly five times greater than that of the soil on which the mud pond is placed (Table 1).

Table 1. Chemical characterization of the sewage sludge and of the soil on which mud pond was placed (medium values for the $0-100 \mathrm{~cm}$ depth)

\begin{tabular}{|c|c|c|c|c|c|c|c|c|c|c|}
\hline \multirow{2}{*}{ Material } & \multirow{2}{*}{$\mathrm{pH}_{\mathrm{H} 2 \mathrm{O}}$} & $\mathrm{CaCO}_{3}$ & $\mathrm{C}_{\text {org }}$ & $\mathrm{Nt}$ & Humidity & \multirow{2}{*}{$\mathrm{C} / \mathrm{N}$} & $\mathrm{N}-\mathrm{NO}_{3}$ & $\mathrm{P}_{\mathrm{AL}}$ & $\mathrm{K}_{\mathrm{AL}}$ & TSC* \\
\hline & & \multicolumn{4}{|c|}{$\%$} & & \multicolumn{4}{|c|}{$\mathrm{mg} \cdot \mathrm{kg}^{-1}$} \\
\hline $\begin{array}{l}\text { Sewage } \\
\text { sludge }\end{array}$ & $7,38 \pm 0,28$ & $7,2 \pm 2,4$ & $13,0 \pm 1,1$ & $0,84 \pm 0,14$ & $128 \pm 68$ & $18,4 \pm 2,3$ & $66 \pm 8,3$ & $174 \pm 88$ & $404 \pm 87$ & $9090 \pm 1300$ \\
\hline Soil & $8,26 \pm 0,21$ & $6,6 \pm 2,3$ & $1,68 \pm 0,68$ & $0,141 \pm 0,05$ & $25,8 \pm 7,1$ & $13,4 \pm 1,1$ & $3 \pm 1$ & $13 \pm 6$ & $339 \pm 94$ & $7050 \pm 7000$ \\
\hline
\end{tabular}

*total salts content

Regarding the total salts content (TSC), it is noted that both materials contain soluble salts at high content, i.e. $9 \mathrm{~g} / 1000 \mathrm{~g}$ sewage sludge and $7 \mathrm{~g} / 1000 \mathrm{~g}$ soil, moreover the soil being deeply salinized. These values indicate a very strong salinization in the sewage sludge and strong in the soil. 


\subsection{The total Zn contents in sewage sludge and in the soil close to mud} pond

Analytical data of total heavy metals contents have highlighted the fact that only the zinc content of sludge exceeds the alert threshold value (2.7 times) and even the intervention threshold (1.3 times) for a soil with a sensitive use of the land (table 2). Other heavy metals analyzed recorded average contents even lower than the average content of soil $(\mathrm{Cr}, \mathrm{Mn})$, slightly higher than that $(\mathrm{Co}, \mathrm{Ni}, \mathrm{Pb})$ or high $(\mathrm{Cd}, \mathrm{Cu})$, but all below the alert threshold for sensitive land use (table 2). Instead, the maximum zinc content $\left(5455 \mathrm{mg} \cdot \mathrm{kg}^{-1}\right)$ reaches a value that exceeds 109 times the normal content of the soil, 7.8 times the alert threshold and 3.6 times that of the intervention threshold (table 3). However, the grouping parameter values are between 1800 and $1900 \mathrm{mg} \cdot \mathrm{kg}^{-1} \mathrm{Zn}$, which indicates that zinc in the sewage sludge generated by this municipal wastewater treatment plant, water that represent a mixture of the domestic and industrial wastewater, is at a very high level of concentration. Industrial wastewaters, although they were initially passed through the factories treatment plants before reaching the city sewerage, however they carried very large zinc content, as a result, in the main, of the zinc coating stations from many existing factories in Iasi city in the past.

Table 2. The medium content of heavy metals $\left(\mathrm{mg} \cdot \mathrm{kg}^{-1}\right)$ in the sewage sludge on-going to soil forming process as comparing with the normal contents in soil (NC), with alert thresholds (AT) and intervention thresholds (IT) for a sensitive use of the land

\begin{tabular}{ccccccccc}
\hline Parameter & $\mathbf{C d}$ & $\mathbf{C o}$ & $\mathbf{C r}$ & $\mathbf{C u}$ & $\mathbf{M n}$ & $\mathbf{N i}$ & $\mathbf{P b}$ & $\mathbf{Z n}$ \\
\hline $\bar{X}$ & 4,90 & 16,4 & 22,5 & 123 & 471 & 39,2 & 61,2 & 1905 \\
$\Sigma$ & 1,10 & 2,3 & 6,3 & 17 & 153 & 9,8 & 11,5 & 1425 \\
\hline $\mathrm{NC}$ & 0,30 & 5 & 30 & 20 & 500 & 20 & 15 & 50 \\
$\mathrm{AT}$ & 5,0 & 100 & 300 & 250 & 2000 & 200 & 250 & 700 \\
$\mathrm{IT}$ & 10,0 & 250 & 600 & 500 & 4000 & 500 & 1000 & 1500 \\
\hline
\end{tabular}

Analysis of the obtained data leads to the conclusion that this sludge despite its high zinc content can be a good fertilizer, especially for the Chernozems soils from the Moldavian Plateau and related geomorphological formations, on which have been reported numerous cases of zinc deficiency in maize (Dornescu et al., 1972).

Installation of wild spontaneous vegetation is a positive signal for the use of such sludge, and at the same time it is a method for reducing the zinc content in the sewage, by its absorption into the plants grown on the mud pond. 
Table 3. Statistical parameters of total zinc contents in sewage sludge and soil on which it is filed $\left(\mathrm{mg} \cdot \mathrm{kg}^{-1}\right)$, as comparing with the normal contents in soil (NC), alert thresholds (AT) and intervention thresholds (IT) for a sensitive use of the land

\begin{tabular}{c|c|c}
\hline \multirow{2}{*}{$\begin{array}{c}\text { Statistic } \\
\text { parameter }\end{array}$} & Sewage sludge & soil \\
\cline { 2 - 3 } & 1057 & 201 \\
\hline $\mathrm{X}_{\min }$ & 5455 & 510 \\
\hline $\mathrm{X}_{\max }$ & 1903 & 275 \\
\hline $\bar{X}$ & 1425 & 107 \\
\hline$\sigma$ & 75 & 39 \\
\hline $\mathrm{CV}(\%)$ & 1875 & 269 \\
\hline $\mathrm{X}_{\mathrm{g}}$ & 1810 & 263 \\
\hline $\mathrm{Me}$ & 1796 & 255 \\
\hline $\mathrm{Mo}$ & & 50 \\
$\mathrm{NC}$ & & 700 \\
$\mathrm{AT}$ & & 1500 \\
$\mathrm{IT}$ & & \\
\hline \hline
\end{tabular}

There are known about 500 species of plants which have capacity to accumulate heavy metals and metalloids. These plants can be divided in two groups: a) plants that accumulate chemical elements regardless of whether nutrient substrate may or may not contain such large amounts of chemical elements and b) plants that accumulate heavy metals or non-metals only if nutritional substrate is rich in these types of chemical elements. They have been called optional hyperaccumulators plants of heavy metals and metalloids (Pollard et al., 2014). It also uses the name of phyto-extractors and phyto-remediators plants. In this category can be included Lolium perenne for phytoremediation of polluted soils and Lemna minor for phytoremediation of heavy metal contaminated wastewater. Researchers conducted by Malschi et al., 2013, under conditions of laboratory experimentation, have highlighted the heavy metals phytoextraction phenomenon from soils and waters polluted by industry.

To this second category can belong even the plants developed on the waste water sewage sludge deposited in the Tomesti mud pond, sludge found in an incipient soil formation process.

2.3. Zinc absorption by the plants developed on the waste water sewage sludge

Excess of water in the sludge (Table 1), originated both from pumping water from the station to the mud pond, but particularly from the rainfall, has created a favorable environment particularly for the reed (Phragmites australis), but also, for other grass species such as Aster panonicum, Rumex acetosella, Chenopodium 
album, Solanum nigrum. There have been reported in small number Galium aparine, Canium maculatum, Urtica dioica. The last species multiplied as growing the area lack of water and sludge has been advancing in soil forming process. Moreover, the use of perennials plants in phytoremediation is known (Cho et al., 2006, Baker et al., 2000).

Analytical dates on the average content of zinc in roots and aerial part of the Phragmites australis plants (table 4) show that these plants grown on the sludge accumulated 30 times more $\mathrm{Zn}$ in the aerial parts, and 46 times more $\mathrm{Zn}$ in the root than Phragmites australis plants grown in a climate zone close to, but uncontaminated. Therefore, this species may be considered a zinc hyper accumulator plant when nutritive substrate offer very high concentrations.

Table 4. The medium content of zinc $\left(\mathrm{mg} \cdot \mathrm{kg}^{-1}\right)$ in Phragmites australis plants developed on the waste water sewage sludge and a submerged soil from an uncontaminated area

\begin{tabular}{ccc}
\hline Substrate & Analyzed plant organ & Zn \\
\hline \hline \multirow{2}{*}{ Sewage sludge } & Aerial part & $473 \pm 227$ \\
& Root & $869 \pm 615$ \\
\hline Unpolluted & Aerial part & $16 \pm 11$ \\
submerged soil & Root & $19 \pm 14$ \\
\hline \hline \multirow{2}{*}{ Enrichment index } & Aerial part & 30 \\
& Root & 46 \\
\hline
\end{tabular}

Table 5. The values of the transfer (TF) in soil and plant and the root-aerial part accumulation index (RAPAI) in plants grown on the sewage sludge on-going to soil forming process

\begin{tabular}{ccc}
\hline Plant nature & TF & RAPAI \\
\hline \hline Aster panonicum & 1,14 & 1,53 \\
Rumex acetosella & 3,02 & 1,84 \\
Chenopodium album & 1,54 & 2,71 \\
Solanum nigrum & 1,62 & 1,91 \\
Phragmites australis & 0,70 & 1,84 \\
\hline \hline
\end{tabular}

Similarly, and the other plants have accumulated large amounts of zinc in both root and the aerial parts (tab.5). For all analyzed species zinc has been accumulated more in the root. Thus, the greatest amount of zinc in the root, as compared with the stem, was accumulated by Chenopodium album, followed in descending order 
by: Solanum nigrum, Rumex acetosella and Aster panonicum, as evidenced by the values of the root-aerial part accumulation index (RAPAI) for $\mathrm{Zn}$. The value of this index for Phragmites australis is equal to that from Rumex acetosella (table 6).

Analyzing soil transfer factor values in the plant (the root and aerial part), we find that the largest amount of zinc was absorbed by Rumex acetosella (table no. $6)$.

Table 6. Average content of zinc $\left(\mathrm{mg} \cdot \mathrm{kg}^{-1}\right)$ of the roots and the part of the main plants grown on sewage sludge under soil forming process.

\begin{tabular}{ccc}
\hline Plant nature & Aerial part & Root \\
\hline \hline Aster panonicum & $860 \pm 534$ & $1318 \pm 356$ \\
Rumex acetosella & $2023 \pm 615$ & $3732 \pm 3000$ \\
Chenopodium album & $794 \pm 167$ & $2148 \pm 1785$ \\
Solanum nigrum & $1063 \pm 826$ & $2026 \pm 1117$ \\
\hline \hline
\end{tabular}

Note that the calculation of these indicators (FT and RAPAI) have used the average values of content for both plant and soil.

Although Phragmites australis has a lower amount of transfer factor, as compared to other herbaceous plants, however, the extent of the area occupied by Phragmites australis as compared with the other plants, make it important in the process of sewage sludge phytoremediation. Also, its participation in the accumulation of zinc in the summary value of all analyzed plants is $10 \%$ in roots and $9 \%$ in aerial part (Fig. 1). It is observed that the most amount of the zinc has been accumulated in Rumex acetosella (35\% in roots and 39\% in aerial parts).

Between the levels of zinc in sewage sludge and the levels of zinc in flora installed on it, direct proportionality relationships, statistically assured, have been established (Fig. 2).

The phenomenon of accumulation of zinc and other heavy metals in plants grown on contaminated soil is known (Greger, 1999, Zhao and Mc. Grath, 2009, Dickinson et al., 2009). Moreover, there are indicator plants for the presence of heavy metal accumulation in soil and subsoil, plants used in biogeochemical prospecting. 

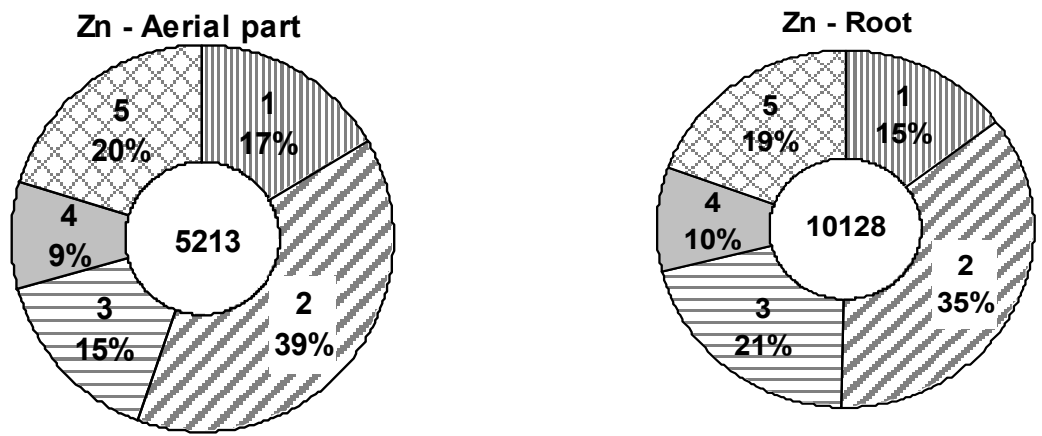

Figure 2. Percentage distribution of $\mathrm{Zn}$ contents of the plants grown on the sewage sludge pond from the wastewater treatment plant of Iaşi, related to total heavy metal total $\left(\mathrm{mg} \cdot \mathrm{kg}^{-}\right.$ ${ }^{1}$ ) accumulated in plants: 1. Aster panonicum, 2. Rumex acetosela, 3. Chenopodium album, 4. Phragmytes australis, 5. Solanum nigrum
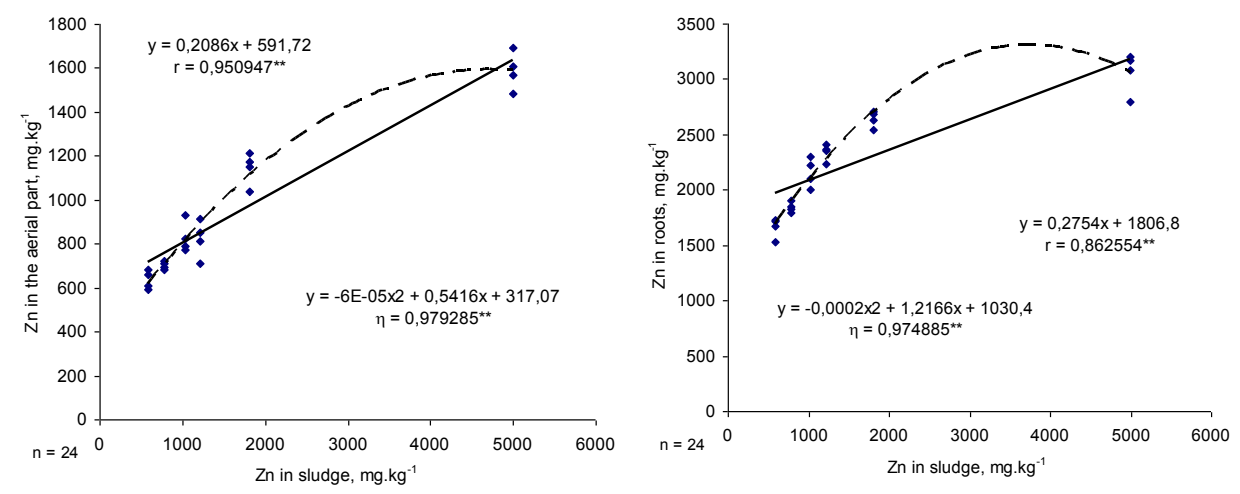

Fig. 3. Correlations between $\mathrm{Zn}$ contents in the sludge and in the flora grown on the mud pond

In the case of plants that are growing on polluted soils, plants that accumulate one or more chemical elements, the intimacy of the phenomenon of absorption of the elements considered to be toxic, such as $\mathrm{Cd}$ and $\mathrm{Pb}$, or of the elements considered in small quantities as nutrients, is not fully clarified. It is assumed as a first phase that occurs a passive absorption of heavy metals in root with complex flow of chemical elements dissolved in the soil solution. From the root in stems, leaves and in the other components of the plants, heavy metals are driven by socalled "carriers" formed by protein specialized in the transport of each type of metal cation. In this process of the transport and accumulation is involved an enzyme adenosine tri phosphate, from whose hydration result adenosine di 
phosphate, free phosphorus and an amount of energy that contribute to heavy metal accumulation. In order to minimize the toxicity of the heavy metals that comes in large quantities in the aerial part of the plant there are involved some genes encoded as $\mathrm{HMA}_{3}, \mathrm{HMA}_{4}$, which are proteins belonging to $\mathrm{P}_{\mathrm{IB}}$ type. Moreover, gene $\mathrm{HMA}_{4}$ with gene $\mathrm{HMA}_{2}$ also have role in metal translocation from root to the aerial part of the plant (Park and Ahn, 2014).

Therefore, phyto-remediation can be a method of reducing zinc content of sludge reduction which can be achieved only over the course of several tens or hundreds of years, if the harvest is collected every year and cremated, the ashes may be a mineral fertilizer with many chemical elements, among which is distinguished zinc, in particular for soils deficient in this nutritive microelement Lacatusu et al., 2012).

Also, sewage sludge as such, after drying and grinding may constitute an organic fertilizer rich in zinc, applicable on soils of Moldavian Central Plateau, where there have been recorded numerous cases of zinc deficiency in maize. In fact, these conclusions regarding the phyto-remediation of sludge deposited in the mud pond, or its use as a fertilizer in agriculture, after a previous grinding and drying, have been emerged from the early research carried out. (Lacatusu et al., 2005).

Marinciuc et al., 2010, also have reported the possibility of phyto-remediation of sludge from wastewater treatment plants.

\section{Conclusions}

- Sewage sludge of municipal and industrial wastewater from Iasi Municipality is deposited in a mud pond with an area of about 15 ha, located in the major floodplain of the Bahlui River on Tomești communal territory.

- Sewage sludge has a weakly alkaline reaction, a medium $\mathrm{CaCO} 3$ content, very high contents of organic carbon and total nitrogen, high, respectively medium contents of phosphorus and potassium in mobile forms, and a strong salinization

- Among the contents of heavy metals, only zinc concentration values exceed by 2,7 times the alert threshold value, and by 1,3 times the value of the intervention threshold for the sensitive use of the land.

- On the sewage sludge was installed a predominantly reed vegetation (Phragmites australis), and secundary herbaceous, consisting of grass species of Aster panonicum, Rumex acetosella, Chenopodium album, Solanum nigrum, species that have absorbed large amounts of $\mathrm{Zn}$ in the root and aerial part.

- Vegetation installed on the mud pond with sewage sludge helps its greening through phyto-remediation, absorbing large amounts of zinc. By vegetation incineration resulting an ash rich in minerals, especially zinc, which may be a 
mineral fertilizer rich in zinc, applicable on the soils deficient in this mineral element.

- Sewage Sludge after drying and grinding is also a good organic fertilizer to Chernozems of Moldavian Central Plateau on which there have been recorded numerous cases of zinc deficiency in maize.

\section{References}

Baker A.J.M., Mc. Grath R.D., Reeves R.D., Smith J.A.C., 2000, Metal Hyperacumulator Plants: A Review of the Ecology and Physiology of a Biochemical Resource for Phytoremediation of Metal polluted Soils. Phytoremediation of Contaminated Soil and Water. Lewis Publ. Boca Raton, FL., By Terry N and Banuelas G. (Ed.), 85-107.

Baker A.J.M., Brooks R.R., 1989, Terrestrial higher plants wich hyperaccumulate metalic elements. A review of their distribution, ecology and phytochemistry, Biorecovery, 1, 81-126.

Cho-Ruk K., Kurukate J., Supprung P., Vetayasuporn S., 2006, Perennial plants in the phytoremediation of lead-contaminated soils, Biotechnology, 5, 1-4.

Dickinson N.M., Baker A.J.M., Doronila A., Laidlaw S., Reeves R.D., 2009, Phytoremediation of inorganics; realism and synergies, International Journal of Phytoremediation, 11, 97-114.

Dornescu D., Pleșa D., Petrovici P. Dorneanu V., 1972, Influence of zinc on maise on Jijia-Bahlui Depression chernozem, Analele ICCPT Fundulea, seria B, 231-245 (in Romanian)

Greger M., 1999, Metal availability and bioconcentration in plants, in Heavy Metal Stress in Plants (Ed. Prasad M.N.V. and Hagemeyer J.) Springer, Heidelberg.

Lăcătușu R., Rizea N., Lazăr R., Kovacsovics B., Matei M.G., Matei S., Lungu M., Preda M., Claciu I., 2005, Level II Environmental Balance and Risk Assessment required for the clearance of sludge storage Tomești, ICPA Bucharest Archive (In Romanian).

Lăcătușu R., Lăcătușu A.-R., Stanciu-Burileanu M.M., Lazăr D.R., Lungu M., Rizea N., Catrina V., 2012, Phytoremediation of a sludge depozit proceeded from a city wastewater treatment plant, Carpathian Journal of Earth and Environmental Sciences, 7, 1,71-79.

Marinciuc Irina Elena, Catrina Virginia, Lăcătușu R., Lazăr Rodica, Topală Daniela, 2010, Research regarding the phyto-rehabilitation of the sludge storage area from wastewater treatment plants, An. Știin. Univ. "Al. I. Cuza" Iași, Geologie, Tomul LVI, 2, 75-81.

Malski D., Roman C., Miclean M., Șenilă M., Ștefănescu L., Malsch-Florian B., Bolonyi A., Ghira G., Brăhaița D., Cuhan A., 2013, Phytoextraction of heavy metals from industrially polluted zone using Lolium perenne and Lemna minor, Environmental Engeneering and Management Journal 12,5, 1103-1108. 
Park W., Ahn S.J., 2014, How do heavy metal ATPase contribute to hyperaccumulation?, J. Plant Nutr. Soil Sci., 177, 121-127.

Pollard A.J. Reeves R.D., Baker A.J.M., 2014, Facultative hyperracumulation of heavy metals and metalloids, Plant Science, 217-218, 8-17.

Zhao F.J., Mc. Grath S.P., 2009, Biofortification and phytoremediation, Curr. Opin. Plant Biol., 12, 373-380. 